ISSN 2519-2523 (print)

Chornomors'ka mynuvshyna. -2019. - No.14.

DOI: $10.18524 / 2519-2523.2019 .14 .187119$

УДК 94(477.7):"1963-1984"

\title{
CHURCH AND RELIGIOUS ACTIVITY OF JOSYF SLIPYI IN THE EMIGRATION (1963-1984 YEARS )
}

\section{Inna Khodak}

Ph.D (History), the teacher of the highest qualification category,

Odessa Educational Complex № 49

"Specialized School -Secondary General Education School for levels I-III"

Odessa City Council in Odessa region

12, David Oistrakh Str., Odessa, 65117, Ukraine

hodak.06@mail.ru

The activity of Josyf Slypiy in the years of his emigration is considered in this article. The process of his hardship religious thoughts has been designated. The role of the pastoral principles in the support of the clandestine with UGCC has been also found out. The emphasis must be placed on the question of Ukrainian patriarchate building. The ideas of J. Slipyi are analysed in the context of the Universal Cathedral decisions and partly the difficulties according to the realization of the Church Union metropolitan question. Metropolitan J. Slipyi became a well-known in the Greek Catholic Church as a believer of the Ukrainian nation. Union.

Key words: Greek Catholic Church, Josyf Slipyi, patriarchate, the Church

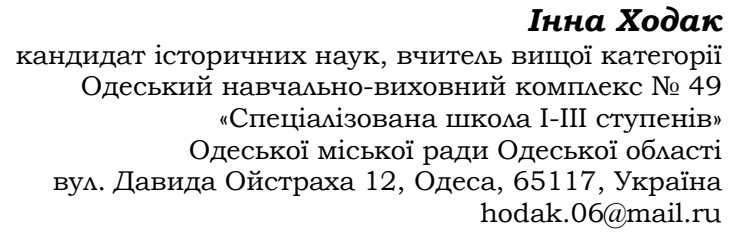

\section{ЦЕРКОВНО-РЕАІГІЙНА ДІЯАЬНІСТЬ Й. САІПОГО В ЕМІГРАЦІї (1963-1984 pp.)}

У поданій статті розглянуто основні напрями діяльності Йосифа Сліпого в еміграиії. Розглянуто проиес еволюиї духовних поглядів митрополита. З'ясовано роль пастирських послань у підтримиі підпільної діяльності УГКЦ на украӥнських землях. Головну увагу приділено питанню створення украйнського патріархату. Проаналізовано ідеї Й. Сліпого в контексті рішень Вселенського собору та окреслено трудноші шодо реалізаиї питання иерковної єдності.

Ключові слова: Греко-католииька иерква, Йосиф Сліпий, патріархат, иерковна єдність.

Митрополит Й. Сліпий увійшов в історію як апологет греко-катомицької церкви й захисник українського народу. Він був сподвижником віри, гідним і достойним послідовником митрополита Андрея Шеп- 
тицького не мише на грунті церковно-ремігійному та богословському, але й національно-патріотичному і суспільно-громадському.

Постать митрополита в радянській історіографії висвітлювалася необ'єктивно. Переважна більшість дослідників ставила за мету дискредитувати суспільно-політичне життя Й. Сліпого і звинуватити у співробітництві 3 нацистськими окупантами. Аише останнім часом з'явилися дослідження, де об'єктивно висвітлюється життєдіяльність Й. САіпого.

Народився майбутній патріарх Йосиф САіпий 17 мютого 1892 р. у селі Заздрість Теребовемьського району Тернопільської області. Зростав він у заможній багатодітній хліборобській глибоко віруючій християнській сім’э. Його дитинство проходимо під впливом батьків, які сприяли не мише тілесному та інтелектуальному розвиткові сина, але й духовному дозріванню у світлі християнських чеснот. Після закінчення гімназії Йосиф САіпий вирішив стати священиком і науковцем. Першу духовну освіту він отримав у Аьвівській духовній семінарії, а згодом продовжив вивчення богослов'я в Іннсбруці та Римі. Після повернення в Україну Й. САіпий отримав посаду професора, а згодом i ректора духовної семінарії. Саме в цей період розпочалася його науководослідницька діяльність, тісно пов'язана з церковно-релігійною. Він став одним із засновників Богословського наукового товариства, де започатковано видання журналу "Богословія".

Варто зазначити плідну співпрацю Й. САіпого 3 митрополитом Андреєм Шептицьким, помічником якого він став 31939 р. Після початку Другої світової війни вони разом пройшли тяжкий шлях радянського переслідування та нелегких випробувань під час німецької окупації. Після смерті А. Шептицького (1944р.) Й. САіпий став митрополитом у складний дмя УГКЦ час. Радянська влада розпочала політику міквідації церкви, яка передбачала арешти і заслання духовенства, в тому числі й митрополита. Упродовж 19 років його життя проходило в радянських тюрмах та таборах. Проте тяжкі випробовування не змамали волю і мужність Й. САіпого.

Більш того, під час перебування в таборах митрополит ніколи не забував про УГКЦ та іï віруючих. Так перебуваючи в таборі Печора в кінці 1948 р. митрополит написав "Різдвяне послання", в якому закликав триматися своєї віри та церкви. У цьому посланні вмадика катакомбної церкви передбачив майбутнє i побачив перемогу борців за Церкву Христову. Він вірив, що "настане час, прийде день, і царство сатани провалиться, а церква і віра Христова житимуть вічно" [1, с. 118].

Завдяки піклуванням папи Іоанна XXIII та світової громадськості 9 жовтня 1963 р. Й. САіпий отримав можливість покинути СРСР i виїхати до Риму. Уже 10 жовтня того ж року відбувся його виступ на другій сесії Ватиканського Собору, заключним акордом якого бумо прохання-пропозиція: "піднести митрополію Києво-Галицьку і всієї Русі до Патріаршої гідності". Саме в цьому митрополит вбачав ієрархічне завершення структури церкви. Свою пропозицію він обгрунтовував тим, що київські митрополити здавна фактично користувалися патріаршими правами. На твердій основі патріархату Київського та всієї Русі бачили 
майбутнє єдиної християнської церкви митрополити XVII ст. П. Могила та Й. Рутський. Ідеї патріархату знайшли своїх прихимьників упродовж 1917-1920 pp. [6, с.153]. Вона була заповітною мрією митрополита Андрея Шептицького.

На Вселенському Соборі Й. Сліпий уперше підняв питання про Київський патріархат, маючи надію, що це буде сприяти об'єднанню християнських церков. Католики і православні є найближчі по крові i вірі, їх єднають традиції рідного християнства, спільні церковні й народні звичаї та спільна двотисячолітня культура, адже саме вони впродовж цімих віків змагалися за збереження самобутньої церкви та іiі повноти [2, с. 151].

Але рішення Йосифа Сліпого зустріли вороже як Москва, так і Рим. Російська православна церква, яка після псевдособору 1946 р. приєднала віруючих офіційно міквідованої УГКЦ, була дуже далекою від подібних ідей. Східна Конгрегація теж відчула, що вона може втратити вмаду над церквою, яку незаконно присвоювала собі впродовж трьох століть. Тож ідея митрополита щодо створення Київського патріархату потрібної підтримки на Соборі не знайшиа [4, с. 163].

Поширенню ідей патріархату сприяв сформований мирянський патріархамьний рух. Виникнувши в 1964 р. у США, він був нечисленним та вже згодом поширився скрізь, де проживала українська діаспора. Новостворений рух був представцений товариствами “За Патріархальний Устрій». Серед них можна видікити: Світове товариство за Патріархат УКЦ з центром у Філадемьфії, Крайове товариство УКЦ, Рада Українських Організацій за Патріархат у Чикаго.

23 грудня 1963 р. Й. САіпий отримав титул Верховного Архієпископа, наданий йому Східною Конгрегацією. Внаслідок цього УГКЦ набула канонічно-церковне оформлення та національне самоуправління. Апемюючи до прав східних церков, Й. САіпий прагнув створити синод єпископів. Він мав бути проведений в 1967 р., але тоді зробити це не вдалося.

Протягом 1968-1976 рр. Й. САіпий відвідав країни Свропи, Австрахії, Америки з метою об'єднання української діаспори і пожвавмення їі церковного життя. Там він знайомився з побутом українців, встановлював релігійні контакти, робив усе можливе для того, щоб дати їм можливість відчути, що українська еміграція становить одну цілісність, пов'язану 3 рідним краєм. Під час першої подорожі 1968 р. відбулася мобілізація і зібрання сил українців діаспори для приїзду на торжество посвячення собору Св. Софії в Римі 27-28 вересня 1969 р. Тоді до Риму прибули усі українські архієреї з діаспори. Користуючись нагодою Й. САіпий скликав у Римі синод єпископів української католицької церкви. Уперше в історії цієї церкви владики української діаспори прислухамись до голосу українського духовенства, чернечих спільнот та мирян і намагалися створити й оформити конституцію патріаршого устрою УКЦ. Зокрема, вони направими на ім'я папи Павла VI послання, в якому просили завершити створення патріархату, помісну католицьку церкву на зразок уже існуючих патріархатів. Однак прохання було відхимено. Свою відмову папа 
мотивував канонічними, пастирськими та історичними проблемами, які виклав у мисті, надісланому Й. Сліпому 7 мипня 1971 р.

Здійснюючи всі ці заходи Й. САіпий доводив, що українські католики всього світу, незважаючи на тяжкі умови свого життя на чужині, мають чималі досягнення: вони зберегли свою церкву в діаспорі й на батьківщині, добилися великих успіхів у іiі розвитку і продовжували змагатися за збереження та зміцнення позицій у моні вселенської апостольської церкви. На думку митропомита, патріарший устрій дозволить об'єднати розпорошені церкви в одну, яка перебуваючи в єдності 3 Апостольським Престолом, мала б зберегти всі свої обрядові традиції і бути під порядкованою центральному керівникові - патріарху. Незважаючи на відмови, Й. Сліпий і далі докладав усіх зусиль дия того, щоб Апостольська Столиця піднесла українську католицьку церкву до патріаршої гідності, але з боку Ватикану порозуміння не було. На всі прохання митрополита приходими негативні відповіді, які пояснювалися правовими, історичними, духовними та душпастирськими міркуваннями. Але фактичною причиною відмови було те, що патріархат української католицької церкви не вкладався у рамки діалогу Ватикан-Москва.

Незважаючи на певні розчарування, Й. САіпий продовжив активну діяльність у напрямі визнання Києво-Галицького патріархату. Під час другої подорожі по українських поселеннях у діаспорі в 1973 р. він побачив, що владики, священики і вірні моляться за нього та поминають його як патріарха. Усвідомлюючи це, Й. САіпий заглибився у вивчення історії становцення патріархатів у I тисячолітті і прийшов до висновку, що вони "не творилися згори, а поставали з низин, саме народ, духовенство та ієрархія починали молитися і поминати предстоятеля певної помісної церкви як патріарха, а згодом Вселенські Собори та Римські архієреї визнавали їх такими [7, с. 11]. На основі таких суджень Й. Сліпий прийняв історичне рішення і вперше підписується під Соборним Вемикоднім посланням як патріарх і кардинал.

12 мипня 1975 р. українським єпископським синодом було проголошено український католицький патріархат, а кардинала Й. САіпого було обрано патріархом. Створення українського патріархату власними силами й акт прийняття патріаршого титулу було важливою історичною подією. Й. Сліпий зазначав "Наш патріархат існує! За ним 400 років змагань, 7 років дійсності, перед ним тільки визнання Апостольського Римського престолу" [7, с. 12].

Проте рішення Й. Сліпого українською ієрархією було сприйнято неоднозначно, що призвело до розколу серед духовенства. 3 його позицією погодилися не всі єпископи української діаспори. Виразну опозицію до створення патріархату висловив Апостольський Екзарх у Великій Британії Августин Горняк. Патріарх Й. САіпий дуже болісно сприйняв цей поділ i висловив свій біль у посланні до українців Великої Британії на Різдво 1976 р. де зазначав, що бажання й утвердження патріархату в українському народі не є гріхом чи злочином. Саме в ньому впродовж багатьох століть український народ бачив свій порятунок і об’єднавчу силу [5, с. 119]. 30 кистопада 1976 р. патріарх Й. САіпий звернувся до своїх єпископів 3 
проханням прибути 13 грудня цього року на аудієнцію до папи. На жаль, на

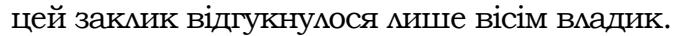

Зустріч 3 папою мала бути присвячена питанню мегалізації патріархату УГКЦ. Йосиф Сліпий звернув увагу папи Павла VI на те, що Другий Ватиканський Собор закликав зберігати традиції і дорогоцінну спадщину східної церкви. Наголошуючи на необхідності визнання патріаршої гідності української католицької церкви, Й. САіпий зазначав: "Дозвольте нам користуватися устроєм, правами, що їх гарантували ваші попередники, а також дозвольте нам правити згідно з канонами східних церков та молитися так, як велить нам наше сумління" [5, с. 115]. Прохання патріарха знову було відхилено, папа наголошував: "в теперішній кон'юнктурі Римська столиця не бачить можливості створити український патріархат і не може погодитися на його становмення". Папа зазначав, що радянський режим у 1946 р. міквідував українську католицьку церкву, вкАючивши іiі незаконно до російської православної, і тому створення українського патріархату викликало б гостру реакцію 3 боку як бімьшовицьких вцастей, так і Московського патріархату [5, с. 105].

3 червня 1976 р. Й. Сліпий написав історичне послання "Про поєднання в Христі", де наголошував, що в Україні діють Католицька і Православна церкви, численні євангельські громади, і всі вони караються за Христа і Христову віру. Ці християнські об'єднання розбиті на різні релігійні групи, які на превеликий жаль, "самі себе поборюють" і тому не в симі об'єднати український народ. Він стверджував, що не існує суттєвої обрядової i догматичної різниці між найчисельнішими українськими церквами - Католицькою та Православною. Це підтверджується теологічними й історичними свідченнями. Якісно новим моментом в історії стало б об'єднання обох гілок українського християнства на тмі патріархату. У посланні Й. Сліпий акцентував свою увагу на такому моменті, як матинізація та полонізація сусідами українців-католиків дия своїх політичних цілей. I для того, щоб не бути мотовилом у чужих ворожих руках, нам треба стати на київські прадавні традиції [3, с. 46].

Й. Сліпого глибоко хвилювали питання єдності в церковно-релігійних та державних справах, що міцно пов'язані між собою. Непорозуміння, а то й відверта ворожнеча між народом та його політичними провідниками гостро вражали патріарха. Вемикої шкоди греко-католицькій церкві іiі розвиткові завдавав перехід вірних української церкви на матинський обряд [5, с. 125]. Й. Сліпий був глибоко переконаний, що Українська катомицька, тобто вселенська, стане тільки тоді католицькою, коли позбудеться матинських впливів.

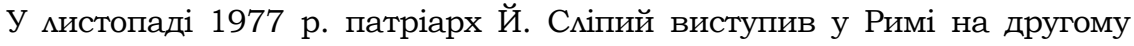
міжнародному слуханні Комітету імені Сахарова із захисту прав мюдини, де звинуватив радянську владу в знищенні Української автокефальної церкви у 1929-1930 рр. та УГКЦ у 1946-1949 рр.

У квітні 1977 р. Й. САіпий спеціально висвятив у Римі трьох Владик дмя України. Ними стали отці Аюбомир Гузар, Степан Чміль та Іван Хома. Кожному 3 них він призначив юрисдикцію над частиною території України. Згідно з декретами Берестейської унії, Й. Сліпий мав повне право 
висвячувати єпископів, повідомивши про це папу. У даному випадку хіротонія відбулася таємно і акт посвячення нових єпископів, призначених дмя церкви в Україні, не узгоджувався з Ватиканом.

У березні 1980 р. надзвичайний Синод призначив Й. Сліпому помічника, яким став Владика Мирослав-Іван Аюбачівський [5, с. 115]. Папа Іван Павло II, без узгодження з патріархом, номінував його Філадельфійським митрополитом 3 правом наслідувати титул діючого предстоятеля церкви, про що офіційно не повідомив [9, с. 149]. Протести патріарха не дали бажаних результатів [8, с. 116]. Основним мотивом, чому патріарх негативно поставився до свого помічника була його поміркованість щодо справи патріархату. Боротьба Йосифа Сліпого за визнання патріархату та за об'єднання українських церков завершилася 1984 р. через його смерть.

Усе своє життя в еміграції Й. Сліпий присвятив справі визнання патріархату дмя УГКЦ і об’єднання усіх християн в одній церкві. Потребу піднесення УГКЦ до патріаршої гідності можна обгрунтувати в історичному, політичному та еклезіальному аспектах. Єдиний патріархат дозволив би об'єднати існуючі митрополії всіх конфесій. Він міг би стати дієвим чинником, який міг би привести до усвідомлення єдності церкви. Проте подібна ідея була досить утопічною, про що свідчать наступні історичні події. Переважна більшість українців проживала в межах Радянського Союзу, належала до православної церкви і не готова була до об'єднання з УГКЦ. Але екуменічна діяльність Й. САіпого відображає багатовікову тугу українського народу за єдністю християнської церкви.

\section{Джерема та мітература:}

1. Бендик М. Еклезіологія Завіщання Бліженнішого Пітріарха Йосифа // Богословія. - Т. 66. - Кн. 3-4. - Аьвів, 2002. - С. 117-128.

2. Гринів О. Й. Сліпий як історик, філософ, педагог. - Аьвів: Місіонер, 1994. - 160 с.

3. Гриньох І. Послання патріарха Йосифа про поєднання в Христі // Богословія. 1977. - № 4. - C. 10-72.

4. Дацько I. Діяльність патріарха Йосифа поза межами Києво-Галицької митрополії // Богословія. - Т. 66. - Кн. 3-4. - Аьвів, 2002. - С. 161-187.

5. До 100-річчя від дня народження Блаженного Йосифа Кардинала Сліпого патріарха Української Греко-Католицької церкви. - Һьвів: Когос, 1991. - 128 с.

6. Заповіт Патріарха. - Аьвів, 2003. - 55 с.

7. Косів М. Києво-Галицький патріархат Української церкви як українська багатовікова туга за єдністю. - Аьвів, 2004. - 19 с.

8. Олійник М. Йосиф САіпий і питання патріархату на сучасному етапі // Нова зоря. - 3 вересня. - № 34. - С. 3-5.

9. Олійник М. Римський період діяльності кардинал Йосифа Сліпого // Кардинал Йосиф Сліпий і сучасність. Всеукраїнська наукова конференція на пошанування 110-ї річниці. - Івано-Франківськ: Пцай, 2002. - С. 142-149.

\section{References:}

1. Bendyk M. (2002) Ekleziologiya Zavishhannya Blizhennishogo Pitriarxa Josyfa. Bogosloviya. T. 66. Kn. 3-4. L'viv [in Ukrainian].

2. Gryniv O. (1994) J. Slipyj yak istoryk, filosof, pedagog. L'viv: Misioner [in Ukrainian]. 
3.Grynox I. (1977) Poslannya patriarxa Josyfa pro poyednannya v Xry`sti. Bogosloviya. № 4. S. 10-72. [in Ukrainian].

4. Daczko I. (2002) Diyalnist patriarxa Josyfa poza mezhamy Kyyevo-Galy`cz`koyi my`tropoliyi. Bogosloviya. T. 66. Kn. 3-4. Lviv [in Ukrainian].

5. (1991) Do 100-richchya vid dnya narodzhennya Blazhennogo Josyfa Kardy`nala Slipogo patriarxa Ukrayins`koyi Greko-Katoly`cz`koyi cerkvy. Lviv: Logos [in Ukrainian].

6. (2003) Zapovit Patriarxa. L'viv [in Ukrainian].

7. Kosiv M. (2004) Ky`yevo-Galy`cz`kyj patriarxat Ukrayinskoyi cerkvy yak ukrayinska bagatovikova tuga za yednistyu. L'viv [in Ukrainian].

8. Olijny`k M. Josy’f Slipy’j i pytannya patriarxatu na suchasnomu etapi. Nova zorya. 3 veresnya. № 34. [in Ukrainian].

9. Olijnyk M. (2002) Ry`ms`ky`j period diyal'nosti kardy'nal Josy’fa Slipogo. Kardy`nal Josyf Slipyj i suchasnist. Vseukrayins'ka naukova konferenciya na poshanuvannya 110-yi richny ‘ci. Ivano-Frankivs` ${ }^{`}$ : Plaj [in Ukrainian].

Инна Ходак

кандидат исторических наук,

учитель высшей категории

Одесский учебно-воспитательный комплекс № 49

"Специализированная школа I-III степеней"

Одесского городского совета Одесской области

УА. Давида Ойстраха 12, 65117, Одесса, Украина

hodak.06@mail.ru

\section{Церковно-религиозная деятельность Иосифа Слепого в эмиграции (1963-1984 г2.)}

В данной статье рассмотрены основные направления деятельности Иосифа Слепого в эмиграиии. Рассмотрен проиесс эволюиии духовных взглядов митрополита. Выяснена роль пастырских посланий в поддержку подпольной деятельности УГКЦ на украинских землях. Главное внимание уделено вопросу создания украинского патриархата. Проанализированы идеи И. Слепого в контексте решений Вселенского собора и обозначены трудности по реализаиии вопроса иерковного единства.

ключевые слова: Греко-католическая иерковь, Иосиф Слепой, патриархат, иерковное единство.

Отримано: 10.12.2019 p. 